\title{
EFL Published Materials: An Evaluation of English Textbooks for Junior High School in Indonesia
}

Rizaldy Hanifa*

English Education Department, Universitas Pendidikan Indonesia, PO box 40154, Jl. Setiabudhi No.229, Isola, Sukasari, Bandung, Indonesia

Corresponding Author: Rizaldy Hanifa, E-mail: rizaldy_eng@student.upi.edu

\section{ARTICLE INFO}

Article history

Received: December 14, 2017

Accepted: March 15, 2018

Published: April 30, 2018

Volume: 9 Issue: 2

Advance access: March 2018

Conflicts of interest: None

Funding: The research is financed by

Indonesia Endowment Fund for

Education (LPDP)

\begin{abstract}
The use of EFL published materials like textbooks are becoming more widespread as they can bring easiness in the classroom by providing teachers with guidelines comprised of syllabus, methodologies, as well as materials for teaching and learning. However, choosing a suitable textbook for their teaching situation is deemed to be one of the most challenging tasks that EFL teachers often face. To get a good picture of the suitability of a textbook, a careful investigation needs to be undertaken. This study focused on the analysis and evaluation of two different English textbooks addressed to junior high schools grade VII in Indonesia, KTSP and curriculum 2013 textbook. Harmer's (2007) framework was employed to figure out the strengths and weaknesses of each textbook. The analysis revealed that both textbooks are quite satisfactory as they are very affordable, contain interesting layout, attractive designs, and clear instructions, correspond to current ELT methodology, cover all language skills, and comprise a wide range of topics which are familiar and culturally appropriate for learners. Nonetheless, the KTSP textbook does not have add-ons and extra materials; meanwhile, curriculum 2013 textbook is weak in providing authentic listening materials. Therefore, although the teachers manage to use the textbooks as their core materials, they are supposed to make adjustment and supplement them with other materials according to their learners' needs and their teaching context.
\end{abstract}

Key words:

EFL Published Materials,

English Textbooks,

Textbook Evaluation,

English Language Teaching,

Junior High School

\section{INTRODUCTION}

An instructional material in teaching becomes one of the important factors that will determine the success of learning. It is defined as anything used by teachers to promote learning for students (Cakir, 2015). Richards (2002) furthermore states that instructional materials are usually provided as the basis for much of the language input that the learners receive and the language practice that occurs in the classroom. In other words, instructional materials are presented to assist the teachers in teaching and learning process. Brown (2001) asserts that the most supportive materials for ELT is textbook. It is safe to say that materials for teaching and learning process in the classroom are mostly found in course book. Many performance activities and the language instructions can also be encountered in course book. Therefore, it is considered an essential component of any EFL program.

However, choosing a suitable textbook for their teaching situation is deemed to be one of the most challenging tasks that EFL teachers often face. Conducting textbook based teaching requires full understanding of the textbook selected as it may have both advantages and drawbacks. Altay (2013) claims that course book can only be effective as long as it increases students' proficiency in foreign language, stimulates teachers to use it in such a good way, and gives the learners the chance of improving their capabilities of conducting a successful interaction with their friends and teachers. Furthermore, Harmer (2007) highlights textbook is useful since it is presented attractively, consists of consistent grammar syllabus as well as appropriate vocabulary exposure and practice, provides teachers with the procedure and extra ideas, and gives learners a chance to prepare for what is coming and review what they have done. On the other hand, Richards (2002) mentions that textbook selected sometimes may not reflect students' needs, can deskill teachers, and might be not affordable for some students. Gebhard (2009), moreover, states that there is possible problem of ideological conflict in teaching beliefs because texts are usually based on the author's or publisher's ideas about teaching. Besides, 
when teachers blindly follow their assigned texts, they might be trivializing the experience for the students. The last, commercially made textbooks are prepared for a wide audience that is culturally diverse and geographically dissimilar. Thus, the selection of the best suitable book for a particular context demands careful investigation.

In general, all materials in textbook are good, it just depends on how the book is used differently by teachers. Brown (2001) states that teachers can have conversations, role-plays, discussions, and chalkboard work, but much of the richness of language instruction is derived from supporting materials. For that reason, it is important for teachers to evaluate the book before relying on it. As a result, they will know the most suitable and appropriate course book. It is important to note that how teachers choose and use the course book in the classroom is not determined by how good a course book is, but it is more likely on how creative teachers in evaluating the course book and choosing which materials is appropriate for the teaching activities. Altay (2013) suggests teachers not to choose a course book without evaluating it thoroughly as neglecting important criteria of course book results in decreasing the success of EFL learners. With this regard, textbook evaluation and selection should be a concept that needs to be concerned by teachers.

Every textbook is definitely supposed to be evaluated before it is used in the classroom. The basic theory about textbook analysis can be seen in Brown (1995) that says that textbook should fit the approaches, needs, syllabus, goals, objectives, and contents of the curriculum. Since not all course books are appropriate with students' condition, teachers are demanded to be creative to modify the course book into something beneficial in helping students meet the objectives of learning. Selecting the learning materials especially course book could be done by analyzing certain areas of the book such as its content, availability and feasibility. While modifying a course book used could be done through omitting, adding, replacing, and adapting certain parts of the book. Adjusting instructional materials with $21^{\text {st }}$ century education is needed to be conducted by the teachers as nowadays learning goal is not only to develop students cognitive but also students' communication, collaboration, critical thinking and creativity skills. In view of that, teachers' responsibility does not only concern with students assessment, but also the evaluation of the teaching and learning process itself which includes the materials. The evaluation and analysis of the textbook obviously will provide better insights into the book's suitability; whether it is relevant to the students' needs, matches the context in which it is going to be used, follows the objectives of learning, as well as fits the teachers' methodology.

A number of studies have been done previously regarding the evaluation of textbook in English language teaching. Fraidan (2012) assessed two books by means of internal and external evaluation. In external evaluation, the books were evaluated briefly for example from what may attract attention. The evaluation was done deeper on the internal evaluation. It was evaluated concerning the language, reading type, authenticity, appropriateness, and culture. Furthermore, Diniah's study (2013) discovered that even though the overall use of textbook fitted teachers and students' needs, required little or no time-consuming preparation for the teachers, attracted students' interests, yet the level of language difficulty in the textbook should be noticed by the teachers. In this regard, Tomlinson (2008) also argues that many ELT materials (especially global course books) currently make many learners of English failed to acquire competence in English and to develop the ability to use it successfully for they are typically more focused on linguistic items rather than on the provision of opportunities for acquisition and development. In addition, Akbari (2015) discovered that textbooks designed and prepared by the Ministry of Education were lack of the variety of communication tasks. The other researches done by Aziz (2014) and Hasanah (2016) that analyzed English textbooks remarked that the textbooks had insufficient listening materials.

Concerning the arguments and current researches, course book assessment is undeniably essential to be carried out in attempt to fully understand the content and style of a book, as well as its strengths and weaknesses, so that the book can be adapted to fit course aims, student needs and teachers' beliefs. A number of experts have constructed many types of textbook evaluation instrument (e.g. Cunningsworth, 1995; Richards, 1998; Brown, 2001; and Harmer, 2007). The present study, nonetheless, only used Harmer's textbook evaluation instrument which consists of some categories for evaluating two junior high school English textbooks in Indonesia. The first category from this textbook evaluation instrument is price and availability. This textbook evaluation instrument considers this category as the most important part to evaluate textbook. Price is very important in choosing the textbook. Thus, the cost of a textbook has to be acceptable for learners (Richards, 1998). The next category from the evaluation instrument belong to add-ons and extras. As textbook serves as a reference source for students, and a support for less experienced teachers (Cunningsworth, 1995), it is much better for the book to contain another source of information such as from different books and internet. As a result, teachers do not only get idea and experience from the main book but they can also elaborate some understanding from other related books and information from internet sites. The other necessary categories in evaluating the textbook include layout and design, instructions, methodology, syllabus, language skills, topics, etc. Those elements are vital to be concerned (Lizt, 2005). Besides, cultural appropriacy is also put into account. As Richards (1998) and Fraidan (2012) say, a course book which is culturally appropriate for learner will make students learn more easily.

From the above elaborations, this present study is undertaken to answer the following question: how is curriculum 2013 English textbook compared to KTSP (school based curriculum) textbook in terms of strengths and weaknesses under the microscope of Harmer's framework? This study is expected to provide useful information for teachers, students, schools, and people who have the same interest on the topic of this study. Furthermore, the result of this study hopefully will be beneficial for teachers and materials developers to support better teaching materials. 


\section{METHOD}

This research was descriptive qualitative research due to the fact that the aim of the research was to analyze two different English textbooks used for junior high school grade VII in order to figure out the strengths and weaknesses of each textbook. To collect the data, this study used documents analysis as the main instrument. There were two textbooks intended to be analyzed and evaluated. The first book was English on Sky 1 for Junior High School Students Years VII published in 2007, consisted of 7 units and 202 pages. This textbook corresponded to KTSP (School Based Curriculum) and was highly used in some junior high schools particularly in Bandung area according to the teachers. The second book was Bahasa Inggris When English Rings a Bell published in 2014, comprised of 11 chapters and 210 pages. The book was related to curriculum 2013 and its use was compulsory to all junior high schools that implemented the curriculum. Therefore, the necessity to analyze and evaluate both books was imposed by the fact that they were used on a large national scale, they were recently developed, and their strengths or weaknesses would have a high impact on students' learning of English.

Meanwhile, the textbook evaluation instrument used was adopted from Harmer (2007). The rationale of choosing this instrument was owing to the fact that English has its own system in which it is inevitable to look over the textbooks' quality under the internationally recognized framework. Hence, it would fulfill both local and international demands of exposures that are useful for providing better insights into the books' suitability. The framework comprised ten important categories along with some possible questions for the consideration to evaluate a textbook (see appendix). The textbooks were examined based on the existence of each category in this instrument. Moreover, the textbooks were analyzed based on the detail questions on each category. This textbook evaluation instrument did not use rank or scoring number. Therefore, it required full opinion from the researcher who evaluated the textbooks. In other words, the textbook evaluation for the present study depended on the opinion of the researcher. The analysis report for this study was in the form of narration.

\section{ANALYSIS AND DISCUSSION}

From the evaluation of the two textbooks, some relevant data have been identified and analyzed. The results of analysis have been organized in terms of strengths and weaknesses found in both textbooks referring to the categories proposed by Harmer. Hence, each data will be presented and discussed in accordance with those categories.

\section{Price and Availability}

In terms of price and availability, both books are very much accessible. The book used for KTSP can be purchased with

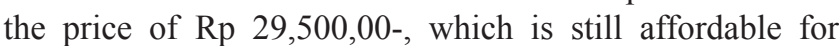
students. The book is also available in bookstores such as Gramedia. Meanwhile, the curriculum 2013 book is avail- able in digital version which can be downloaded free from the internet. Students who face difficulty in finding the book online may request the digital version from their teachers at their schools. Both books do not have separated extra materials such as workbook, but instead include various activities and exercises inside. Students using these books have the advantage to get all-in-one textbooks. Therefore, they are good value for money. Richards (1998) and Harmer (2007) believe that cost of a textbook should be acceptable for learners. It is important to note that even though the book is great and attractive, yet it is expensive, then it will be meaningless for students since they cannot buy it. Thus, this category needs to be paid attention to.

\section{Add-ons and Extras Category}

In this category, the KTSP textbook is lacking on add-ons and extra materials. There are no internet sites to be used as additional learning source. Whereas, textbook should give a reference source and support teacher's development (Cunningsworth, 1995). It is supported by Litz (2005) that states good textbook can be very useful for professional growth. Hence, providing extra workbooks and other relevant information is needed. On the other hand, even though curriculum 2013 textbook does not provide extra workbook, the book includes some extra activities or materials apart from the main exercise and materials. Some of the materials are taken from the internet and sometimes accompanied by internet address, for example, on page 61 chapter 3 , an activity to complete short dialog based on the pictures accompanied by internet address. Thus, students can independently browse for more detailed information from the internet. This promotes the use of ICT in learning. Suherdi (2015) along with Wilkinson (2016) claim that the integration of technology as materials can establish high quality teaching and learning in nowadays education. However, the internet sites are missing in several extra materials. Thus, teachers and students still have limited source of learning source.

\section{Layout and Design Category}

In the aspect of layout and design, the KTSP book English on Sky clearly reflects its title. The front cover shows a boy playing roller skates with the sky background. This gives the impression that learning English can be easy, fun, enjoyable, practical activity: to learn by playing. With the good pick of colors, the book looks even more attractive and energetic and gives cheerful atmosphere. Richards (1998) points out that a textbook should be interesting by showing attractive and colorful format. Meanwhile, the front cover of curriculum 2013 Bahasa Inggris When English Rings a Bell focuses more on the sense of unity as it shows a globe and several hands, from fair to colored skin, holding the globe. It gives an impression that English is a language that brings everyone from different areas, races, and backgrounds together and that everybody can learn English. Both books are attractive in their own ways, but the later stresses more on the importance to learn English to face global world. Since first impression gives impact to one's perception about the 
books, they have to be attractive. This is supported by Harrer, Kachalov, Borodin, and Kachalova (2015), who mention attractiveness will influence on forming positive interest to mastering a foreign language.

The contents of these books, especially the texts within both KTSP and curriculum 2013, are very clean and well-ordered. Furthermore, the activities and materials are not too wordy and they are available with some related pictures and illustrations. The KTSP textbook mostly provides realistic pictures such as people from different countries. This surely gives students chance to know how people across the world may look like. In curriculum 2013 textbook, however, the pictures presented are mostly in the form of cartoons or animations featuring students, teachers, and etc. which can also be used for brainstorming activity. The illustrations are even better because they are full-colored, both in materials and exercises. Anjaneyu (2014) claims that the colorful illustrations contained in the textbook make the book more appealing to learner. Then, books are supposed to be evaluated briefly from what may attract students' attention (Fraidan, 2012). Apart from that, these textbooks have met the demand of English for $21^{\text {st }}$ century. According to Suherdi (2015), nowadays, texts contain various semiotic resources, not only language, but also various kinds of image such as photos, emoticons, tables, scientific symbols, etc.

\section{Instructions Category}

Instructions on the KTSP and curriculum 2013 books are very clear with simple and understandable language. By reading the instructions, students would know what they should do in each unit and exercise, which skill they need to use; whether it is listening, speaking, reading, or writing, and whether the tasks should be done individually or not. Nonetheless, there was a minor ungrammatical sentence found in KTSP textbook on page 45 , in which the instruction says "do you these activities before you go to school?" As a consequence, students may not get the meaning of the instruction. Furthermore, in the curriculum 2013 textbook, some instructions do not clearly state what language skills students need to use to complete the tasks given. An example has been taken from the instruction on page 90 , in which it is written "please describe the picture." Even though the instruction is clear, whether students are expected to describe it in spoken or written form is not known. Thus, the language used must be easily understood by learners. In this regards, Tomlinson (2011) strongly claims that materials should help learners to feel at ease. It means materials should make learners feel comfortable because when the learners feel anxious or uncomfortable toward the materials, they are highly likely lose opportunities for language learning.

\section{Methodology Category}

In the KTSP textbook, the methodology of learning is designed to focus more on students' progress. This is also known as student-centered learning or also known as learner autonomy. Jacobs and Renandya (2016) suggest that learner autonomy enables students become more independent and responsible on their own learning. The exercises are provided as guidance for students to find out about the materials and practice more on the language aspects. For example, in unit 1 of English on Sky task 9, students are asked to listen and complete a dialog between two people. The activity is followed by true false questions to check students' understanding about the dialog. At the end, students are required to create their own dialog, using the expressions and their comprehension about the language focus presented in previous tasks.

Similarly, the curriculum 2013 textbook Bahasa Inggris When English Rings a Bell also aims to make students active in their learning, only through the scientific approach involving learning steps such as observing, questioning, associating, experimenting, and networking. Thus, tasks in the book are designed to follow this approach. Lengkanawati (2017) mentions that the implementation of curriculum 2013 gives new expectations in the learning process since the curriculum expects that there should be a change in the teaching and learning process, from transferring knowledge or giving information by the teacher to the students to allowing students to find information by themselves. Suherdi (2013) also states that the objective of curriculum 2013 will be achieved by paying attention to the educational content, switching the learning paradigm from the teacher centered approach into student-centered approach. This learning paradigm will foster learner autonomy which means students will become more independent of teachers and more responsible for their own learning.

For example, in chapter 7 , students learn the things around them. They are expected to be able to identify and describe things. The whole activities in the unit start from labelling pictures about things in the classroom. Then, they are asked to find out about rooms at school and things in their bags. Then, they make questions about the things and need to write the answers as well. At the end of this unit, students are supposed to link their knowledge by doing a project to make labels for their schools, as shown on page 132. The task also involves students to describe their favorite things, rooms, and animals along with the pictures. These activities which are closely related to students' daily life also promotes contextual learning. Mustafa (2010) says that children learn better from direct experiences and from scripts which serve as their guidelines in understanding the lesson based on what they have experienced before.

In an essence, the textbooks consist of appropriate methodology; they cover the syllabus; and have clear instructions. Methodology which includes aims, and approaches; the instruction of the book; and the organization's overall curriculum (syllabus) are important criteria that a textbook should have (Litz, 2005).

\section{Syllabus Category}

Based on the analysis on the books' syllabus, both KTSP and curriculum 2013 are suitable for Junior High School Grade VII's learning. Cunningsworth (1995) suggests a textbook should be a syllabus which reflects learning objectives. Byrd (2001) in Lawrence (2011: 4) also emphasizes the first thing that should be considered in developing and analyzing 
the textbook is its fitness with the curriculum which comprises syllabus. For that reason, the textbook should fit the current syllabus that teacher use so that he/she can make the textbook itself becomes a syllabus.

The syllabus inside the KTSP book supports the learning objectives of the curriculum. There are at least ten expressions (introducing, commanding, giving information, apologizing, giving and asking for something, likes and dislikes, clarification, giving facts, giving opinion and prohibiting) and six functional texts (announcement, shopping list, greeting card, instruction, descriptive texts, and procedure) that are expected to be learned by the first grade Junior High School based on the syllabus. Almost all of them covered in this textbook. Introducing expression is covered in unit 1 (introducing oneself and others); commanding is in unit 2; giving information is in unit 4; apologizing is in unit 3; giving and asking for something is in unit 5; unit 3 discusses likes and dislikes expression; clarification is in unit 2; giving facts is covered in unit 7; giving opinion is in unit 5; and prohibiting is found in unit 2. Meanwhile, for functional text, announcement is covered in unit 2; shopping list is found in unit 4; greeting card is discussed in unit 1 ; instruction is in unit 2; descriptive text is in unit 5 and 6; and procedures text is in unit 7. Hence, the contents of this textbook are suitable and appropriate for the first grade Junior High School syllabus.

On the other hand, the textbook of curriculum 2013 are basically composed based on the curriculum announced by the Minister of Education and Culture (2013), which makes it very suitable with the learning objectives. The objectives of the curriculum include 10 expressions (e.g. greetings, goodbyes, giving thanks, asking and showing apologies, introducing oneself, giving information and facts (names of days and daily activity), giving opinion, giving command and prohibition), 3 functional texts (descriptive text covering describing people, animal, and place along with adjective), label and list, notices, warning, and caution), and 2 other focused aspects (rhyming words, singular and plural nouns). Expressions of greetings, goodbyes, giving thanks, and asking and giving apologies are covered in chapter 1 and 4; introducing is in chapter 2; giving information and facts about names of days and daily activities are in chapter 3 and 5; giving opinion is in chapter 5; giving command and prohibition are in chapter 10. The functional texts in this book focus more on aspects of descriptive text and its various themes, which are discussed in chapter 4 (describing people), 8 (describing people and animals, as well as adjectives related to them), 9 (describing people, place, animals, and things), and 11 (describing favorite people, animals, and places). The label and list are covered in chapter 7 while giving command and prohibition are presented in chapter 10. Meanwhile, other language aspects such as rhyming words and singular and plural nouns are also available in chapter 6 .

\section{Language Skills Category}

Both KTSP and curriculum 2013 textbooks demand students to use the four language skills: listening, reading, writing, and speaking. A textbook can also be classified as good textbook if it has specific language functions, grammar, and skills content (Lizt, 2005) and these textbooks have complete four skills content. Anjaneyu' study (2014) found that authors of good books always intended to use real-like situation and explore all four language skills in an integrated way.

In KTSP textbook, the skills are in order and have almost balanced portion. Mostly, learning process starts with listening in which students listen to a conversation before practicing the dialog with a partner. After that, the students are asked to read the text whose topic is relevant with the dialog. Finally, they are asked to write complete text using their own language. For example, the lesson on unit 5 discusses about description. Students listen to a conversation while at the same time they have to complete the missing parts. Then, they practice the conversation with their friends. These activities are intended to improve students' listening and speaking skills. In the next activity, students answer questions by reading the dialog that they have completed before. The last activity is students write their own sentences and practice the dialog with their friends.

Even though the curriculum 2013 textbook also promotes the four language skills, the portions for each skill is not well-balanced. The chapters of the book emphasize more on productive skills which are speaking and writing. According to the Deputy Minister of Education and Culture (2014), one of English instructional objectives in curriculum 2013 is to develop students' communicative competence both in spoken and written forms in order to achieve the literacy level of information. Thus, it explains why the language skills practices are not divided evenly in the book. As can be seen, chapter 1 comprises of 11 speaking activities (e.g. activity 2, $3,4,5,7,8,10,11,16,18$, and project task), 8 writing activities (e.g. activity $7,8,10,12,14,16,18$, and project task), 4 reading activities (e.g. activity 1, 9, 13, and 15) and 2 listening activities (e.g. activity 6, and 17). Chapter 9 involves 12 activities for speaking (e.g. activity 4, 5, 6, 7, 10, 11, 12, 13, $14,15,17$, and 18), 10 activities for writing (e.g. activity 3 , $5,14,15,16,17,18,19,20$, and project task), 3 activities for reading (e.g. activity 1,2 , and 8 ), and 1 activity for listening (e.g. activity 9).

In this book, listening activities are usually concerned with pronunciation practice in which students repeat after their teacher. Aziz (2014) points out curriculum 2013 strongly suggests teachers and students to use the textbooks which have been developed by the government (the Ministry of Education and Culture law number 71 year 2013). It is seen that

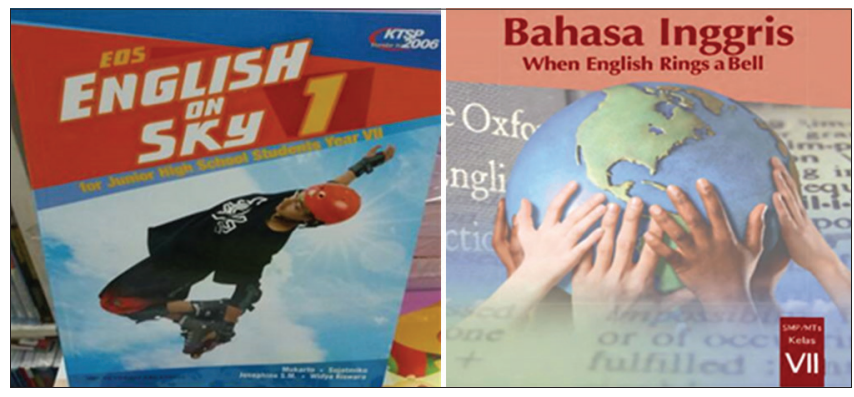

Covers of KTSP textbook (left) and curriculum 2013 textbook (right) 
the English textbook for the seventh-grade students which is entitled "When English Rings a Bell" (WERB) does not have adequate listening materials. Thus, teachers need additional listening materials. This is supported by Maftoon, Kargozari and Azarnoosh (2016) who believe that one goal of listening instruction is to help learners to understand real life language. This means that students need to be exposed to authentic materials, as suggested by Tomlinson (2011) about principle of good materials that they should expose learners to language in authentic use. However, Hasanah (2016) notes this as a weakness of the textbook: the listening skill involved in the textbook has no audio from native speaker since it is so difficult to look for the audio with native speaker voice. For covering these weaknesses, the developer designed the activities of listening skill guided by the teacher. Meanwhile, reading activities mostly focus on vocabulary and expression building for certain topics.

\section{Topics Category}

In the aspect of topics, it is clearly analyzed that both KTSP and curriculum 2013 books have various range of topics. In KTSP book, there are different kinds of expressions being introduced on each unit. Therefore, students are always introduced with new topics in every unit. For example, one topic in unit 2 is asking for information. Meanwhile in unit 3, students learn more about how to express likes and dislikes. Similar findings are noted on the curriculum 2013 textbook. However, due to the difference in syllabus, the topics being presented might not be the same as the ones in KTSP. For example, topic in chapter 1 largely involves expressions about greetings, goodbyes, thanksgiving, and apologies. The topic in chapter 2 is about introducing oneself and others. Chapter 3 discusses the topics related to daily activities, giving information and giving facts based on names of the days, the dates, the months, and the years. The chosen topics are all related to our daily communication, in which we introduce ourselves, ask for information, express our likes and dislikes, mention our daily activities, etc. Rashidi and Safari (2011) mentions that source of the themes of the materials should be derived from the learners' life situations, needs and interests. Tomlinson (2012) adds that learners need a lot of experience of the language being used in a variety of different ways for a variety of purposes. Thus, students would know the essence of the language. Hence, the selection of these topics can be deemed as good.

\section{Cultural Appropriacy Category}

The topics in both KTSP and curriculum 2013 textbooks are culturally appropriate for Indonesian students. The contents found in the books such as names, places, and traditions are based on facts about Indonesia. For example, English on Sky page 11 includes information about Indonesia people' names and some familiar places in Indonesia. It is also noted that page 146 introduces descriptive text about a store which is very popular in Yogyakarta. As a result, students do not only learn about the descriptive text, but they also gain more knowledge about the place.
In the curriculum 2013 textbook, the information presented are likely to be different. Some cultural-oriented topics noted are about Indonesian traditional food on page 160 and the Celebrated National Days on page 60-61, accompanied by the pictures of Indonesian famous and influential people. The aim is nonetheless to help students achieve learning objectives as well as understand more about their own culture. As Richards (1998), Fraidan (2012), and Anjaneyu (2014) assert, a coursebook should be appropriate for learners and based on their culture. Thus, materials designers should create and produce more local materials in textbook (Elham \& Reza, 2013).

\section{Teacher's Guide}

There is no teacher's guide is provided in these textbooks. Essentially, a textbook should have an accompanying teachers' guide to help teachers with procedure and give extra ideas (Harmer, 2007). This weakness, however, can be overlooked because the instructions in both textbooks are very clear and easy to follow.

\section{CONCLUSIONS}

As already mentioned, this study tried to examine two ELT textbooks used for junior high school grade VII in order to figure out the strengths and weaknesses of each textbook. Overall, the analysis results of this study revealed that both textbooks written for English language learning are satisfactory. In terms of price and availability, the two books are very much affordable and accessible. In addition, the books contain interesting layout and attractive designs which suit students' interest. The activities and materials found in the textbooks are mostly accompanied with some related pictures and illustrations. However, the pictures presented are not quite the same. The KTSP textbook generally comes up with realistic pictures; conversely, in curriculum 2013, the pictures illustrated tend to be in full-colored animation forms. Therefore, the colorful illustrations contained in the textbook make the book more appealing to learners. Apart from that, both KTSP and curriculum 2013 textbooks are also well organized and written that make students easy to learn.

Furthermore, the analysis highlights that either KTSP or curriculum 2013 textbook corresponds to current ELT methodology. In the KTSP textbook, the teaching methodology is set to concentrate on students' progress. By the same token, the curriculum 2013 textbook stresses student-centered paradigm through the scientific approach involving learning steps such as observing, questioning, associating, experimenting, and networking. Moreover, the textbooks are relevant to their own syllabus. As a result, the learning objectives can be achieved. All language skills are covered in the two textbooks as well. In KTSP textbook, the skills are designed in order through all the units (e.g. listening, reading, writing and speaking) and have almost balanced portion. On the other hand, the curriculum 2013 book emphasizes more on productive skills. The activities for receptive skills are usually used as input for the activities of the productive 
skills. Besides, the materials included in the textbooks are appropriate for leaners' needs, cultures, and interests comprising a wide range of topics.

The present analysis also detect the problematic areas of both textbooks. The KTSP textbook does not have add-ons and extra materials. There are no internet sites to be used as additional learning source. Contrariwise, even though curriculum 2013 textbook does not provide extra workbook, the book takes account of some extra activities or materials taken from internet sites. Nonetheless, the internet sites are not always found in extra materials which then lead students to have limited information of learning source. The other problem identified in curriculum 2013 textbook is the lack of authentic material especially for listening skill. The language of native speakers is not presented in any of the tasks. Listening activities are usually concerned with pronunciation practiced by repeating what the teachers say. As a consequence, students might not be able to understand English used for real life communication.

Based on the results of the study, the following suggestions are made. First of all, teachers who are currently involved in the process of English language learning and teaching should be trained to be more conscious and critical of what goes on in the materials they teach. Although the teachers manage to use the textbooks as their core materials, they are supposed to make adaptation and supplement them with other materials according to learners' needs and their teaching context. Second, the writers of the textbooks should conduct a regularly retrospective evaluation of their books and make the necessary adjustment to constantly update and improve them. Third, as this study only focuses on the analysis merely based on the perception of the outsider evaluator, further research can be conducted to reveal more objective and in-depth analysis by combining the evaluation with the interview with teachers and student users.

\section{REFERENCES}

Akbari, Z. (2015). Current challenges in teaching/learning English for EFL learners: The case of junior high school and high school. Procedia - Social and Behavioral Sciences, 199,394-401.https://doi.org/10.1016/j.sbspro.2015.07.524

Altay, B. (2013). Strategies for textbook selection and evaluation in terms of four main skills for EFL classrooms. International Journal of Psycho-Educational Sciences 4(4), 23-41.

Anjaneyu, T. (2014). A critical analysis of the English language textbooks in Andhra Pradesh, India. ELT Research Journal, 3(4), 181-200.

Aziz, M., S., A. (2014). Developing listening supplementary materials for the seventh-grade students based on curriculum 2013. Paper Presented at the 61 TEFLIN International Conference, October 7-9, 2014, English Education Department Teacher Training and Education Faculty, Sebelas Maret University, Solo.

Brown, H. (2001). Teaching by principles: an interactive approach to language pedagogy. Englewood Cliffs: Prentice Hall.

Brown, J. D. (1995). The Elements of Language Curriculum. Boston, Massachusetts: Heinle\&Heinle Publishers.

Cunningsworth, A. (1995). Choosing Your Coursebook. Oxford: Heinemann.
Cakir, I. (2015). Instuctional Materials Commonly Employed by Foreign Language Teachers at Elementary schools. Student views of instructor-student rapport in the college classroom. International Electronic Journal of Elementary Education, 8(1), 69-82.

Deputy Minister of Education and Culture (2014). Konsep dan implementasi kurikulum 2013. Jakarta: Kementerian Pendidikan dan Kebudayaan.

Diniah, S. N. (2013). Teacher's Perceptions towards the Use of English Textbook in EFL Classroom. Journal of English and Education, 1(2), 72-81.

Elham, N. M. \& Reza, P. (2013). Analysis of English language textbooks in the light of English as an International Language (EIL): A comparative study. International Journal of Research Studies in Language Learning, 2(2), 83-96. DOI: 10.5861/ijrsll.2012.163

Fraidan, A. A., (2012). Evaluation of Two ESP Textbooks. Canadian Center of Science and Education, 5(6), 43-47.

Gebhard, J. G. (2009). Teaching English as a Foreign or Second Language: A Self-Development and Methodology Guide. USA: The University of Michigan Press.

Harmer, J. (2007). How to teach English. China: Pearson Education Limited.

Harrer, I.A., C., Kachalov, N.A., Borodin, A.A., \& Kachalova, O.I. (2015). Sociocultural component in the content of teaching foreign languages to pre-school children. Procedia - Social and Behavioral Sciences, 166, $344-$ 350. Doi: 10.1016/j.sbspro.2014.12.534

Hasanah, I. (2016). Developing English Materials for Character Building Based on 2013 Curriculum for Eighth Grade Students. IJOLTL, 1(2), 111-126.

Jacobs, G. M. \& Renandya, W. A. (2016). Student-centred learning in ELT. In Renandya, W. A. \& Widodo, H., P. (2016). English language teaching today: Linking theory and practice. Switzerland: Springer.

Lawrence, W. P. W. (2011). Textbook evaluation: a framework for evaluating the fitness of the Hong Kong new secondary school (NSS) curriculum. Dissertation for Master Program, City University of Hong Kong. Retrieved from http://www.asian-efl-journal.com/Thesis/ Thesis-Wong.pdf on December 20, 2017.

Kemendikbud. (2014). Bahasa Inggris, when English rings a bell (Edisi Revisi). Jakarta: Kemendikbud.

Lengkanawati, N. S. (2017). Learner Autonomy in the Indonesian EFL Settings. Indonesian Journal of Applied Linguistic, 24(2), pp. 222-231.

Litz, D. R. A. (2005). Textbook evaluation and ELT management: a South Korean case study. Asian EFL Journal. Retrieved from: http://www.asian-efljournal.com/ Litz_thesis.pdf.

Maftoon, P., Kargozari, H., R., \& Azarnoosh, M. (2016). Some guidelines for developing listening materials. In Azarnoosh, M., Zeraatpishe, M., Faravani, A., \& Kargozari, H., R. (Eds.). (2016). Issues in Materials Development. Rotterdam: Sense Publishers.

Minister of Education and Culture. (2013). Kurikulum 2013 kompetensi dasar: Sekolah Menengah Pertama (SMP)/ Madrasah Tsanawiyah (MTs). Jakarta: Kementerian Pendidikan dan Kebudayaan. 
Mukarto, Josephine, Sujatmiko, \& Kiswara, W. (2007). English on sky 1 for junior high school students year VII. Jakarta: Penerbit Erlangga.

Musthafa, B. (2010). Teaching English to young learners in Indonesia: Essential Requirements. Educational. 4, 120-125.

Rashidi, N. \& Safari, F. (2011). A model for EFL materials development within the framework of critical pedagogy (CP). English Language Teaching, 4(2), 250-259. Doi:10.5539/elt.v4n2p250

Richards, J. C. (1998). Beyond training. Cambridge: Cambridge University Press.

Richards, J. C. (2002). Curriculum development in language teaching. New York: Cambridge University Press.

Suherdi, D. (2013). Buku pedoman penyelenggaraan pendidikan profesi guru Bahasa Inggris: Buku ajar pemantapan kompetensi akademik 3.1. Bandung: Celtic Press

Suherdi, D. (2015). English for $21^{\text {st }}$ century Indonesia. Pa- per presented at English Education International Conference (EDUTICON), November 4 - 5, 2015, English Education Study Program, University of Jambi, Jambi.

Tomlinson, B. (2008). Language acquisition and language learning materials. In Tomlinson, B. (Eds). (2008). English language teaching materials: A critical review. London: Continuum.

Tomlinson, B. (2012). Materials Development. In A. Burns \& J. C. Richards (Eds.). (2012). The Cambridge guide to pedagogy and practice in second language teaching. Cambridge: Cambridge University Press.

Tomlinson, B. (2011). Introduction: principles and procedures of materials development. In Tomlinson, B. (Eds.). (2011). Materials Development in Language Teaching ( $2^{\text {nd }}$ ed.). Cambridge: Cambridge University Press.

Wilkinson, M. (2016). Language learning with ICT. In Renandya, W., A. \& Widodo, H., P. (2016). English language teaching today: Linking theory and practice. Switzerland: Springer. 


\section{APPENDIX}

The textbook evaluation instrument adopted from Harmer (2007)

\begin{tabular}{|c|c|}
\hline Areas for consideration & Questions for coursebook analysis \\
\hline Price and availability & $\begin{array}{l}\text { How much does the coursebook cost? } \\
\text { Will students have to buy any extra } \\
\text { material (workbook, etc)? } \\
\text { Are all the components (workbook, coursebook, etc) } \\
\text { available? } \\
\text { What about the levels? } \\
\text { Is this good value for money? } \\
\text { How much does the whole package cost? }\end{array}$ \\
\hline Add-ons and extras & $\begin{array}{l}\text { Apart from a workbook, what other extras are offered } \\
\text { with the course? } \\
\text { Are there internet sites with extra materials (exercises, } \\
\text { texts, etc.)? } \\
\text { What values should we place on the extras that are } \\
\text { available? }\end{array}$ \\
\hline Layout and design & $\begin{array}{l}\text { Is the book attractive? } \\
\text { Is its design appropriate for the students and the } \\
\text { teacher? } \\
\text { Does the design of the book make it easy to follow? }\end{array}$ \\
\hline Instructions & $\begin{array}{l}\text { Are the instructions clear and unambiguous? } \\
\text { Are they written in language that the students will } \\
\text { understand? }\end{array}$ \\
\hline Methodology & $\begin{array}{l}\text { What kind of teaching and learning does the } \\
\text { coursebook promote? } \\
\text { Is there a good balance between study and activation? }\end{array}$ \\
\hline Syllabus & $\begin{array}{l}\text { Is the syllabus appropriate for our students? } \\
\text { Does it cover the language areas that we would } \\
\text { expect? } \\
\text { Does the coursebook build in a feeling of progress? }\end{array}$ \\
\hline Language skills & $\begin{array}{l}\text { Does the coursebook have the appropriate balance of } \\
\text { skills? } \\
\text { Are the skill activities likely to engage students? }\end{array}$ \\
\hline Topics & $\begin{array}{l}\text { Does the book contain a variety of topics? } \\
\text { On balance, are the topics appropriate for the kind of } \\
\text { students who will use the coursebook? }\end{array}$ \\
\hline Cultural appropriacy & $\begin{array}{l}\text { Is the material appropriate for the cultural situation } \\
\text { that the students are in? } \\
\text { Do the texts contain culturally insensitive material? } \\
\text { Are the activities appropriate for the learning culture? } \\
\text { Is the coursebook unprejudiced in the way it deals with } \\
\text { different customs, ethnicities, races, and sexes? }\end{array}$ \\
\hline Teacher's guide & $\begin{array}{l}\text { Does the coursebook have an accompanying } \\
\text { teacher's guide? } \\
\text { Is it easy to use? } \\
\text { Does it explain things clearly? } \\
\text { Does it offer alternatives to the coursebook } \\
\text { activities? }\end{array}$ \\
\hline
\end{tabular}

